\title{
ANALISIS RISIKO PRODUKSI DAN FAKTOR-FAKTOR YANG MEMPENGARUHINYA PADA USAHATANI JAGUNG (Zea mays $L$.) DI KECAMATAN MEMPAWAH HULU KABUPATEN LANDAK
}

\author{
Dewi Kurniati \\ Staf Pengajar Jurusan Sosial Ekonomi Pertanian Fakultas Pertanian UNTAN
}

\begin{abstract}
This study aims to analyze the production risk of maize farming and also find effect of using maize farming input toward the production risk. The method used in this study is a survey method. The location is determined by purposive. Data obtained through interviews with 60 randomly simple maize farmers. The method used is coefficient of variation (CV) analysis and multiple linear regression analysis with heteroscedastic method. The results showed that the production risk of maize farming with land area $<1$ ha higher than maize farming with land area 1 ha. The production risk is influenced by labor, with coefficient value is -0.027 and probability value is 0.09 . The number of labor significantly influence the variation of maize production, so that means additional labor affect production risk of maize farming.
\end{abstract}

Key words: risk, production, maize farming 


\section{PENDAHULUAN}

Jagung merupakan komoditas palawija utama di Indonesia ditinjau dari aspek pengusahaan dan penggunaan hasilnya, yaitu sebagai bahan baku pangan dan pakan. Kebutuhan jagung terus meningkat seiring dengan meningkatnya permintaan bahan baku pakan. Komposisi bahan baku pakan ternak unggas membutuhkan jagung sekitar $50 \%$ dari total bahan yang diperlukan (Sarasutha, 2002). Kondisi ini membuat budidaya jagung memiliki prospek yang sangat menjanjikan, baik dari segi permintaan maupun harga jualnya. Terlebih lagi setelah ditemukan benih jagung hibrida yang memiliki banyak keunggulan dibandingkan dengan benih jagung biasa. Keunggulan tersebut antara lain, masa panennya lebih cepat, lebih tahan serangan hama dan penyakit, serta produktivitasnya lebih banyak.

Pasar komoditas jagung di Kalimantan Barat sangat terbuka luas, mengingat bahwa produksi jagung Kalimantan Barat belum mampu memenuhi permintaan pasar lokal. Kebutuhan jagung ini terutama untuk pakan ternak ayam atau ternak lainnya. Salah satu daerah yang mengusahakan usahatani jagung di Kalimantan Barat adalah Kabupaten Landak. Kabupaten Landak merupakan daerah yang berpotensi untuk dikembangkan dengan usahatani jagung karena merupakan salah satu daerah yang sesuai untuk ditanami tanaman jagung dilihat dari sumber daya lahan yang luas, minat petani yang tinggi, serta masih tingginya harga jagung di pasaran. Berdasarkan pada data tahun 2005-2009 menunjukkan bahwa perkembangan produktivitas per luas lahan jagung daerah Kabupaten Landak semakin meningkat.

Petani jagung di Kecamatan Mempawah Hulu pada umumnya adalah petani yang masih memiliki lahan usaha skala kecil dan modal yang terbatas. Penggunaan sarana produksi terutama pupuk yang sangat dibutuhkan petani terganggu akibat penggunaan pupuk oleh petani tidak sesuai dengan rekomendasi. Keterbatasan faktor-faktor produksi berupa besarnya luas lahan yang diusahakan dan input lainnya merupakan faktor yang selama ini dapat mempengaruhi hasil produksi. Hal ini pada akhirnya juga akan berpengaruh terhadap tingkat pendapatan dan kesejahteraan petani jagung.

Sebagaimana yang terjadi pada semua komoditi pertanian, terutama yang diusahakan oleh petani, persoalan pokok adalah masalah produksi dan pemasaran (Anwar dalam Tahir, 2011). Masalah produksi berkenaan dengan sifat usahatani yang selalu tergantung pada alam didukung faktor risiko karena penggunaan pupuk kimia yang tidak sesuai anjuran, menyebabkan tingginya peluang-peluang untuk terjadinya kegagalan produksi, sehingga berakumulasi pada risiko rendahnya pendapatan yang diterima petani.

Berdasarkan hal tersebut, maka analisis terhadap risiko usahatani jagung sangat penting untuk dilakukan. Penelitian yang dilakukan bertujuan untuk menganalisis risiko usahatani jagung serta pengaruh penggunaan input usahatani jagung terhadap risiko produksi di Kecamatan Mempawah Hulu Kabupaten Landak.

\section{METODE PENELITIAN}

Metode yang digunakan dalam penelitian ini adalah metode survey. Lokasi penelitian ditentukan dengan sengaja (purposive) dengan dasar pertimbangan bahwa Kecamatan Mempawah Hulu merupakan salah satu daerah produksi jagung yang cukup tinggi. Desa Tunang merupakan Desa penghasil jagung terbesar di Kecamatan Mempawah Hulu, sehingga Desa Tunang dipilih sebagai sampel desa untuk mewakili Kecamatan Mempawah Hulu. Pengambilan sampel petani jagung dalam penelitian ini ditetapkan dengan metode sampel acak sederhana ( Simple Random Sampling) sebanyak 60 kepala keluarga (KK) petani dari seluruh petani jagung di Desa Tunang yang 
terdiri dari 30 orang petani dengan luas lahan $1 \mathrm{Ha}$ dan 30 orang petani dengan luas lahan $<1 \mathrm{Ha}$.

Analisis risiko usahatani jagung meliputi analisis risiko produksi usahatani jagung. Untuk mengetahui besarnya risiko produksi dianalisis dengan menggunakan koefisien variasi $(\mathrm{CV})$. Koefisien variasi (CV) merupakan ukuran resiko relatif yang diperoleh dengan membagi standar deviasi dengan nilai yang diharapkan (Pappas dan Hirschey,1995). Secara matematis risiko dirumuskan sebagai berikut:

$$
C V=\frac{\sigma}{\bar{Y}}
$$

Keterangan : CV $=$ Koefisien Variasi, $\sigma=$ Standar Deviasi, $\bar{Y}=$ rata-rata dari suatu nilai (nilai dari produksi)

Nilai koefisien variasi yang lebih kecil menunjukkan variabilitas nilai rata-rata pada distribusi tersebut rendah. Hal ini menggambarkan risiko yang dihadapi untuk memperoleh produksi tersebut rendah.

Besarnya pengaruh penggunaan input terhadap risiko produksi dianalisis dengan menggunakan regresi linier berganda dengan metode heteroscedastic. Model heteroscedastic yang digunakan adalah model multiplicative heteroscedasticity dengan memaksimumkan fungsi likelihood (Just and Pope dalam Roumasset et al. 1976; Greene, 1993). Model regresi untuk pengaruh penggunaan input terhadap produksi dan terhadap risiko produksi secara umum dituliskan sebagai berikut:

$$
\begin{aligned}
\operatorname{Ln} Y= & \eta_{0}+\eta_{1} \ln X_{1}+\eta_{2} \ln X_{2}+\eta_{3} \ln X_{3}+\eta_{4} \ln X_{4}+\eta_{5} \ln X_{5}+\eta_{6} \ln X_{6}+\varepsilon \\
& \varepsilon^{2}=\theta_{0}+\theta_{1} \ln X_{1}+\theta_{2} \ln X_{2}+\theta_{3} \ln X_{3}+\theta_{4} \ln X_{4}+\theta_{5} \ln X_{5}+\theta_{6} \ln X_{6}+\varepsilon
\end{aligned}
$$

\section{Keterangan :}

$\mathrm{Y}=$ Produksi jagung $(\mathrm{kg})$

$\varepsilon^{2}=$ Risiko produksi jagung (residual)

$\mathrm{X}_{1}=$ Luas lahan $(\mathrm{Ha})$

$\mathrm{X}_{2}=$ jumlah benih $(\mathrm{Kg})$

$\mathrm{X}_{3}=$ jumlah tenaga kerja (HOK)

$\mathrm{X}_{4}=$ jumlah pupuk UREA $(\mathrm{Kg})$

$\mathrm{X}_{5}=$ jumlah pupuk NPK $(\mathrm{Kg})$

$\mathrm{X}_{6}=$ jumlah herbisida (It)

$\eta_{0}, \theta_{0}=$ intersep

$\eta_{i}, \theta_{i}=$ koefisien parameter yang diestimasi

$\varepsilon=$ error term

Uji statistik terhadap model regresi terdiri atas tiga macam pengujian yaitu uji koefisien determinasi $\left(R^{2}\right)$, likelihood ratio test dan Individual test (Uji-t). Nilai koefisien determinasi $\left(R^{2}\right)$ digunakan untuk mengetahui ketepatan model yang digunakan. 


\section{HASIL DAN PEMBAHASAN}

\section{Karakteristik Responden Petani jagung}

Karakteristik responden yang ada pada petani dapat dilihat dari berbagai segi, diantaranya karakteristik petani menurut kelompok umur, tingkat pendidikan, jumlah anggota keluarga, dan pengalaman berusahatani.

\section{Umur Petani}

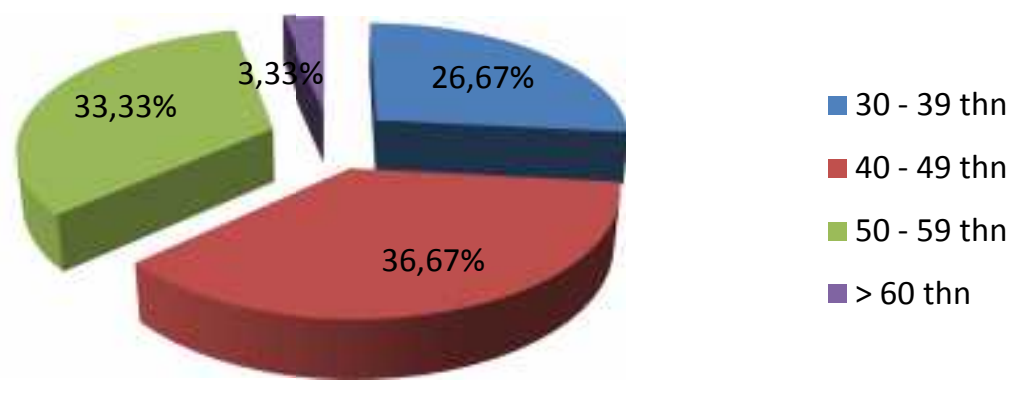

Gambar 1. Distribusi Responden Menurut Kelompok Umur Pada Usahatani Jagung

Berdasarkan pada gambar 1 diatas menunjukkan bahwa sebagian besar responden berada pada kelompok umur produktif. Persentase tertinggi pada kelompok umur 40 - 49 tahun sebesar 36,67\%. Pada kelompok umur produktif tentunya dapat mempengaruhi keberhasilan dalam mengelola dan menjalankan usahatani, terutama dalam mempengaruhi fisik serta cara berfikir petani.

\section{Tingkat Pendidikan}
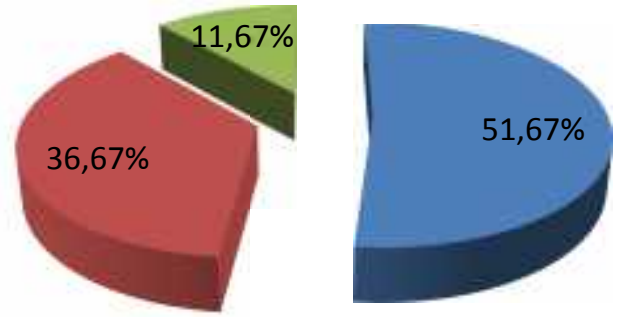

$$
\begin{aligned}
& \text { SD } \\
& \text { SMP } \\
& \text { SMA }
\end{aligned}
$$

Gambar 2. Distribusi Responden Menurut Tingkat Pendidikan Petani Pada Usahatani Jagung

Berdasarkan pada gambar 2 diatas menunjukkan bahwa $51,67 \%$ petani responden memiliki tingkat pendidikan SD. Semakin tinggi tingkat pendidikan petani, maka akan semakin mudah pula petani tersebut menyerap informasi, baik melalui media koran, buku maupun penyuluh. 


\section{Jumlah Anggota Keluarga}

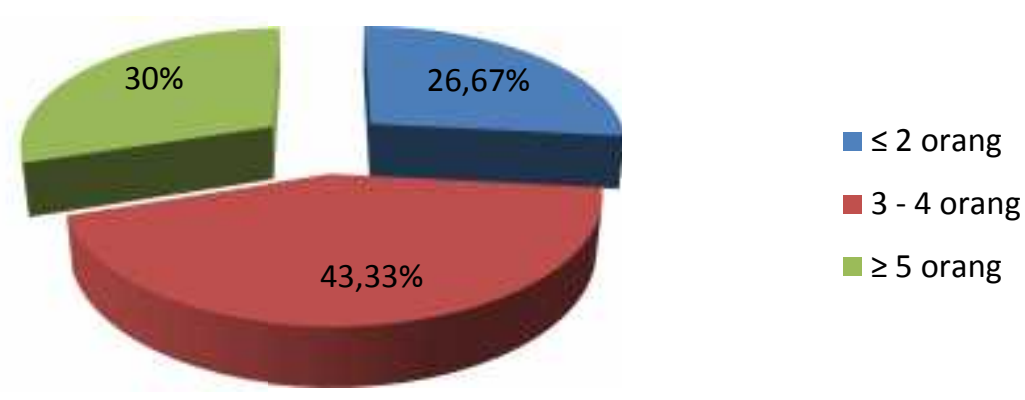

Gambar 3. Distribusi Responden Menurut Jumlah Anggota Keluarga Pada Usahatani Jagung

Berdasarkan gambar 3 diatas menunjukkan bahwa sebagian besar yaitu 43,33\% jumlah anggota keluarga petani responden sebanyak $3-4$ orang. Jumlah anggota keluarga berpengaruh terhadap taraf kehidupan suatu keluarga. Semakin banyak jumlah anggota keluarga, semakin besar beban tanggungan keluarga. Namun disisi lain banyaknya anggota keluarga akan dapat dimanfaatkan untuk mengelola usahatani yang dimiliki atau dengan kata lain jumlah anggota keluarga dapat menjadi sumber tenaga kerja, khususnya bagi anggota keluarga yang telah memasuki umur produktif dan belum berkeluarga.

\section{Pengalaman Usahatani}

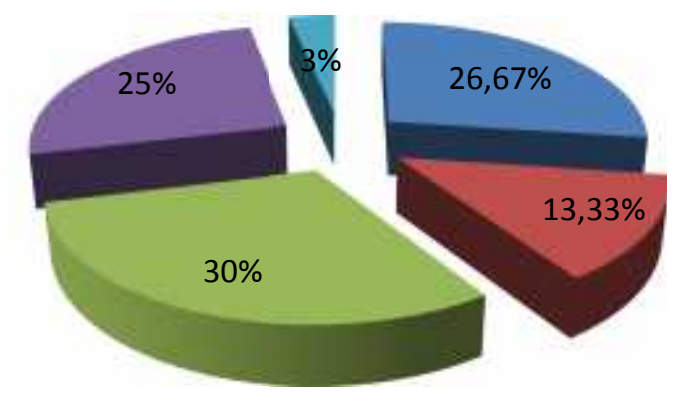

$$
\begin{aligned}
& -10-15 \text { thn } \\
& 16-21 \text { thn } \\
& 22-27 \text { thn } \\
& -28-32 \text { thn } \\
& \geq 33 \text { thn }
\end{aligned}
$$

Gambar 4. Distribusi Responden Menurut Pengalaman Usahatani Pada Usahatani
Jagung

Berdasarkan gambar 4 diatas menunjukkan bahwa sebesar $30 \%$ petani memiliki pengalaman dalam berusahatani jagung selama $22-27$ tahun. Pengalaman usahatani responden ini akan berpengaruh terhadap usahatani yang dilaksanakan. Semakin lama pengalaman yang dimiliki petani maka akan lebih mudah bagi petani dalam menjalankan usahataninya. 


\section{Risiko Produksi}

Analisis risiko produksi menggunakan koefisien variasi (CV) kemudian dilakukan perbandingan risiko produksi antara petani jagung dengan luas lahan $<1 \mathrm{Ha}$ dan petani jagung dengan luas lahan $1 \mathrm{Ha}$. Nilai koefisien variasi produksi yang kecil menunjukkan variabilitas nilai rata-rata produksi yang rendah. Hal ini menggambarkan risiko produksi yang dihadapi untuk mendapatkan hasil produksi tersebut kecil, demikian sebaliknya. Perbandingan risiko produksi antara usahatani jagung dengan luas lahan $<1 \mathrm{Ha}$ dan petani jagung dengan luas lahan $1 \mathrm{Ha}$ dapat dilihat pada Tabel 1.

Tabel 1. Perbandingan Risiko Produksi Pada Usahatani Jagung dengan luas lahan $<1$ $\mathrm{Ha}$ dan luas lahan $1 \mathrm{Ha}$.

\begin{tabular}{lcc}
\hline \multirow{2}{*}{ Uraian } & \multicolumn{2}{c}{ Produksi Usahatani Jagung (Kg/UT) } \\
\cline { 2 - 3 } & Luas Lahan < 1Ha & Luas Lahan 1 Ha \\
\hline Rata-rata Produksi & 3.640 & 6.540 \\
Standar Deviasi & 637,67 & 561,77 \\
Koefisien Variasi (CV) & 0,18 & 0,086 \\
CV (\%) & 18 & 8,6 \\
\hline
\end{tabular}

Sumber : Analisis Data Primer, 2012

Berdasarkan hasil analisis dapat dikaji pada Tabel 1 menunjukkan bahwa risiko produksi usahatani jagung dengan luas lahan $<1$ Ha lebih tinggi dibandingkan usahatani jagung dengan luas lahan $1 \mathrm{Ha}$. Hal ini mengindikasikan bahwa adanya variasi produksi yang lebih tinggi pada usahatani jagung dengan luas lahan $<1 \mathrm{Ha}$ dibanding usahatani jagung dengan luas lahan $1 \mathrm{Ha}$.

\section{Faktor-faktor yang Mempengaruhi Risiko Produksi Jagung}

Untuk mengetahui risiko produksi jagung pada input atau faktor-faktor produksi jagung dapat dianalisis menggunakan model fungsi produksi Cobb-Douglass menurut Just and Pope, dimana model tersebut menunjukkan adanya pengaruh faktor-faktor produksi terhadap produksi jagung. Hasil analisis fungsi Cobb-Douglas dapat dilihat pada tabel 2.

Tabel 2. Faktor-faktor Yang Mempengaruhi Produksi Jagung di Kecamatan Mempawah Hulu Kabupaten Landak

\begin{tabular}{lcccc}
\hline \multicolumn{1}{c}{ Variabel } & Koefisien & Std Error & t-hitung & Prob \\
\hline C & $5.213126^{* * *}$ & 0.869864 & 5.993039 & 0.0000 \\
LAHAN & $0.334989^{* *}$ & 0.164956 & 2.030776 & 0.0473 \\
BENIH & $0.620934^{* * *}$ & 0.169820 & 3.656433 & 0.0006 \\
TK & $-0.086401^{*}$ & 0.059084 & -1.462353 & 0.1495 \\
UREA & $0.382192^{* * *}$ & 0.142370 & 2.684510 & 0.0097 \\
TSP & $0.190065^{\text {ns }}$ & 0.189507 & 1.002944 & 0.3204 \\
HERBISIDA & $-0.414346^{* * *}$ & 0.156471 & -2.648075 & 0.0106 \\
\hline R-squared & 0.843891 & ${ }^{* * *}=$ signifikan 1\% & & \\
Adjusted R-squared & 0.826218 & ${ }^{* *}=$ signifikan 5\% & & \\
F-statistic & 47.75095 & ${ }^{*}=$ signifikan 10\% & & \\
& & ns $=$ tidak signifikan & & \\
\hline
\end{tabular}

Sumber : Analisis Data Primer, 2012 
Berdasarkan hasil analisis yang tersaji pada tabel 2 diketahui bahwa nilai koefisien determinasi $\left(R^{2}\right)$ sebesar 0,844 . Hal ini berarti sebanyak 84,4 persen variasi dari produksi jagung dapat dijelaskan oleh variasi variabel independen dalam model, dengan kata lain 84,4 persen variabel independen secara bersama-sama berpengaruh terhadap produksi dan sisanya 15,6 persen dipengaruhi oleh hal lain yang tidak diteliti. Hasil uji menunjukkan bahwa nilai $F$ hitung $(\alpha=1 \%)$ sebesar 47,75 lebih besar dari $F$ tabel $(3,34)$, berarti bahwa variabel independen secara bersama-sama berpengaruh nyata terhadap produksi jagung.

Hasil uji t menunjukkan bahwa koefisien regresi yang berpengaruh nyata terhadap produksi jagung adalah lahan, benih, tenaga kerja, pupuk UREA, dan herbisida. Hal ini berarti setiap penambahan atau pengurangan faktor produksi tersebut akan menaikkan produksi jagung.

Kemudian untuk mengetahui faktor-faktor yang mempengaruhi risiko produksi jagung adalah estimasi dengan Method Least Square dengan menggunakan paket komputer program Eviews. Hasil analisis secara lengkap tersaji pada Tabel 3.

Tabel 3. Faktor-faktor Yang Mempengaruhi Risiko Produksi Usahatani Jagung di Kecamatan Mempawah Hulu Kabupaten Landak.

\begin{tabular}{|c|c|c|c|c|}
\hline Variabel & Koefisien & Std Error & t-hitung & Prob \\
\hline $\mathrm{C}$ & $-0.058986^{n s}$ & 0.241890 & -0.243853 & 0.8083 \\
\hline LAHAN & $-0.033573^{\text {ns }}$ & 0.045871 & -0.731908 & 0.4674 \\
\hline BENIH & $0.007710^{\text {ns }}$ & 0.047223 & 0.163261 & 0.8709 \\
\hline TK & $-0.027826^{*}$ & 0.016430 & -1.693635 & 0.0962 \\
\hline UREA & $0.041884^{\mathrm{ns}}$ & 0.039590 & 1.057948 & 0.2949 \\
\hline TSP & $-0.003526^{\mathrm{ns}}$ & 0.052698 & -0.066916 & 0.9469 \\
\hline HERBISIDA & $-0.010471^{\text {ns }}$ & 0.043511 & -0.240651 & 0.8108 \\
\hline R-squared & 0.074773 & $=$ signifikan $1 \%$ & & \\
\hline Adjusted R-squared & -0.029970 & ** $=$ signifikan $5 \%$ & & \\
\hline F-statistic & 7.713871 & * = signifikan $10 \%$ & & \\
\hline & & $\mathrm{ns}=$ tidak signifikan & & \\
\hline
\end{tabular}

Sumber : Analisis Data Primer 2012

Berdasarkan hasil analisis yang tersaji pada Tabel 3 diketahui bahwa nilai $\mathrm{F}$ hitung $(\alpha=10 \%)$ sebesar 7,713 lebih besar dari $F$ tabel $(1,95)$, berarti bahwa variabel independen secara bersama-sama berpengaruh nyata terhadap risiko produksi. Hasil uji $\mathrm{t}$ terhadap variabel independen menunjukkan variabel independen yang berpengaruh nyata dan negatif terhadap risiko produksi usahatani jagung adalah tenaga kerja.

Nilai koefisien determinasi $\left(R^{2}\right)$ sebesar 0,074. Hal ini berarti sebanyak $7,4 \%$ variasi dari risiko produksi jagung dapat dijelaskan oleh variasi variabel independen dalam model, dengan kata lain 7,4 \% variabel independen secara bersama-sama berpengaruh terhadap risiko produksi dan sisanya 92,6\% dipengaruhi oleh hal lain yang tidak diteliti yang merupakan variabel lain di luar model, hal tersebut antara lain adalah pengaruh cuaca dan hama penyakit.

\section{Interpretasi Model Fungsi Produksi dan Risiko Produksi}

\section{Luas Lahan}

Variabel luas lahan berpengaruh positif dan signifikan terhadap produksi jagung dan berpengaruh tidak signifikan dan negatif terhadap risiko produksi jagung di Kecamatan Mempawah Hulu Kabupaten Landak. Nilai koefisien variabel lahan pada 
model yang menunjukkan elastisitas variabel luas lahan terhadap risiko produksi jagung adalah sebesar $-0,03$. Dilihat dari nilai probabilitasnya 0,47 , hal ini menunjukkan bahwa luas lahan tidak berpengaruh signifikan terhadap tingkat variasi hasil produksi jagung. Hal ini berarti penambahan luas lahan meningkatkan produksi jagung namun tidak berpengaruh terhadap risiko produksinya.

\section{Benih}

Koefisien benih bertanda positif dan berpengaruh signifikan terhadap produktivitas jagung, dan memiliki tanda positif tapi tidak berpengaruh signifikan terhadap risiko produksi jagung. Hal ini disebabkan karena terdapat petani memiliki lahan yang cukup luas dalam usahatani jagung sehingga penambahan benih akan meningkatkan produksi jagung. Namun hal ini tidak berpengaruh signifikan terhadap risiko produksi jagung.

\section{Tenaga kerja}

Variabel tenaga kerja memiliki koefisien regresi negatif dan berpengaruh signifikan terhadap produksi jagung dan terhadap risiko produksi. Hal ini berarti peningkatan jumlah tenaga kerja akan menurunkan produksi jagung. Didalam kegiatan budidaya jagung petani menggunakan tenaga kerja yang banyak dalam memaksimalkan kegiatan usahatani. Hal tersebut dikarenakan banyaknya tenaga kerja yang tersedia dan terlibat dalam kegiatan usahatani jagung. Besarnya jumlah tenaga kerja berpengaruh signifikan terhadap tingkat variasi hasil produksi jagung, sehingga berarti penambahan tenaga kerja juga mempengaruhi risiko produksi jagung.

\section{Pupuk UREA}

Penggunaan pupuk Urea berpengaruh positif dan signifikan terhadap produksi jagung namun tidak berpengaruh signifikan terhadap risiko produksi jagung. Hal ini berarti adanya penambahan pupuk Urea sebesar 1\% akan meningkatkan produksi jagung sebesar $0,38 \%$. Artinya peningkatan penggunaan pupuk Urea akan diikuti oleh peningkatan produksi sampai batas tertentu yang dibutuhkan oleh tanaman. Namun jumlah pupuk UREA tidak berpengaruh signifikan terhadap variasi hasil produksi jagung.

\section{Pupuk TSP}

Penggunaan pupuk TSP bernilai positif tidak berpengaruh signifikan terhadap produksi jagung dan bernilai negatif tidak berpengaruh signifikan terhadap risiko produksi jagung. Hal ini ditunjukan dari nilai probabilitas 0,32 terhadap produksi jagung dan 0,94 terhadap risiko produksi yang berarti tidak terdapat pengaruh signifikan terhadap hasil produksi maupun variasi hasil produksi jagung.

\section{Herbisida}

Koefisien regresi variabel herbisida memiliki tanda negatif dan berpengaruh nyata terhadap produksi jagung. Hal ini berarti penambahan penggunaan herbisida $1 \%$ akan menurunkan produksi jagung sebesar 0,41 \%. Sedangkan koefisien regresi herbisida terhadap risiko produksi memiliki tanda negatif, namun hasil uji t menunjukkan bahwa herbisida tidak berpengaruh nyata terhadap risiko produksi.

\section{KESIMPULAN DAN SARAN}

Berdasarkan hasil penelitian, maka ditarik kesimpulan sebagai berikut:

1. Risiko produksi usahatani jagung dengan luas lahan $<1$ Ha lebih tinggi dibandingkan usahatani jagung dengan luas lahan $1 \mathrm{Ha}$. Hal ini mengindikasikan bahwa adanya variasi produksi yang lebih tinggi pada usahatani jagung dengan luas lahan $<1 \mathrm{Ha}$ dibanding usahatani jagung dengan luas lahan $1 \mathrm{Ha}$. 
2. Faktor yang mempengaruhi risiko produksi adalah tenaga kerja, dengan nilai koefisien $-0,027$ dan nilai probabilitas 0,09. Besarnya jumlah tenaga kerja berpengaruh signifikan terhadap tingkat variasi hasil produksi jagung, sehingga berarti penambahan tenaga kerja mempengaruhi risiko produksi jagung.

Sebagai implikasi kebijakan dari penelitian ini, maka di sarankan beberapa hal sebagai berikut:

1. Menambah penggunaan input produksi yang secara signifikan meningkatkan produksi dan menurunkan risiko.

2. Keterbatasan penelitian ini adalah hanya menggunakan faktor-faktor produksi sebagai variabel yang mempengaruhi risiko. Penelitian lanjutan perlu juga untuk dilanjutkan dengan menggunakan variabel sosial ekonomi dalam mempengaruhi risiko produksi.

\section{DAFTAR PUSTAKA}

Adisarwanto dan Yustina Erna. 2000. Meningkatkan Produksi Jagung. Penebar Swadaya : Jakarta.

Anwar, 1995. Studi Kebijaksanaan Nilai Tukar Pertanian. Bogor: Kerjasama P4E dengan Departemen Ilmu-ilmu Sosial Ekonomi, Fakultas Pertanian, Institut Pertanian Bogor

Greene, W.H. 1993. Econometric Analysis (Second Edition). Toronto: Macmilan Publishing Company.

Gujarati, D. 1991. Ekonometrika Dasar. Penerbit Erlangga. Jakarta.

Just, R.E, dan R.D. Pope. 1976. On The Relationship of Input Decision and Risk. Roumasset, J.A. Boussard, J.M, Singh I. (eds). Risk Uncertainty and Agricultural Development. New York: Agricultural Development Council.

Muzdalifah, Masyhuri, Any S. 2012. Pendapatan dan Risiko Pendapatan Usahatani Padi Daerah Irigasi dan Non Irigasi Kabupaten Banjar Kalimantan Selatan. Jurnal Sosial Ekonomi Pertanian, Volume 1, Nomor 1, April 2012, hlm 65-74.

Nazir, Moh. 1983. Metode Penelitian. Ghalia Indonesia: Jakarta.

Pappas, J.M dan Hirschey, Mark. 1995. Ekonomi Manajerial Edisi. Keenam Jilid II. Bina rupa Akasara. Jakarta.

Robert, G.D, and J.H. Torrie. 1993. Prinsip dan Prosedur Statistika Suatu Pendekatan Biometrik, Jakarta: Gramedia Pustaka Utama.

Roumasset, J.A. 1976. Risk Aversion, Indirect Utility Function Market Failure, In: Roumasset, J.A, Boussard, J.M, Singh, I. (eds) Risk and Uncertainty an Agriculture Develop-ment. New York: Agriculture Development Council.

Sarasutha, 2002. Kinerja Usahatani dan Pemasaran Jagung di Sentra Produksi. Jurnal Litbang Pertanian 21(2).

Tahir, A.Gaffar. 2011. Analisis Risiko Produksi Usahatani Kedelai Pada Berbagai Tipe Lahan di Sulawesi Selatan. Jurnal Sosial Ekonomi Pertanian, Volume 8, Nomor 1, Februari 2011. 